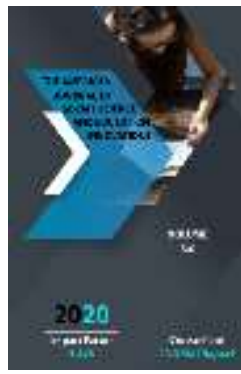

\title{
History Of Irrigation In Uzbekistan \\ (1950-1990)
}

\section{Oybek Komilov}

Doctor Of Sciences (DSC) In History, Professor At The "Theory Of Civil Society" Department Of Andizhan State University, Andizhan, Uzbekistan

\section{Journal Website:}

http://usajournalshub.c om/index,php/tajssei

\section{Copyright: Original} content from this work may be used under the terms of the creative commons attributes 4.0 licence.

\section{ABSTRACT}

In the article it is analyzed the policy of the centre of the further strengthening mono cultural clap in Uzbekistan that in undertaken measures on building of large irrigation canals and pumping stations in republic on the bases of archival sources and a historical material in 50-80 XX century.

\section{KEYWORDS}

Irrigation, irrigation canal, pumping station, siphon, collector, drainage, Soviet government, centre, cotton monopoly.

\section{INTRODUCTION}

By the second half of the 2oth century, the Soviet government, having outlined the appropriate political and economic goals in Uzbekistan, began to introduce into practical life a policy related to the development of the irrigation system and the construction of reclamation facilities. Therefore, in order to effectively use irrigation lands in the republic, the possibilities of agricultural mechanization were increased, the area of irrigated fields was increased, special attention was paid to the implementation of measures for leveling irrigation fields, number of resolutions were adopted relating to the development of the irrigation-reclamation industry. 


\section{METHODS}

In particular, in 1952, on March 13, a resolution of the Council of Ministers of the USSR "On the progress of restructuring irrigation channels and transition to a new irrigation system" was adopted [1]. According to him, in the republic of 1.5 million hectares of fields, soil works were carried out in the amount of 570 million $\mathrm{m}^{3}, 24$ machine-excavator stations (MES) were organized in the network of the Ministry of Water Resources of the Republic $[2, p .106]$. And at the same time, the issue of expanding the irrigation fields was considered in a resolution adopted in February 1954 by the Council of Ministers of the USSR and the Central Committee of the CPSU. According to this decree, out of 600 thousand hectares of irrigated fields in the republic, cotton fields expanded to 300 thousand hectares [3, p.94]. It was from this period that irrigation and reclamation works in the republic were entirely subordinated to the cotton monopoly. But the carried out irrigation work, in turn, made it possible to develop new lands and increase the yield of cotton.

\section{RESULTS AND DISCUSSIONS}

Beginning in 1955, a struggle began in the Soviet state under the slogan "Subordination of nature to the will of the people", a doctrine was formed called "For irrigation from sources you can take as much water as you like, their size is unlimited". The reason for this state during the Soviet period was the development of small and medium-sized fields for irrigation. At the same time, the development of industry and a sharp increase in the population required the use of water resources in large quantities. But, almost without paying attention to the above, the main goal was to obtain a continuous harvest from cotton fields. The cotton harvest plan did not take into account local conditions and increased year after year. In particular, in 1956, 2 million 900 thousand tons of cotton were grown in Uzbekistan, and this, in turn, in relation to 1955 amounted to a harvest of over 400 thousand tons [4, p.204]. The development of irrigation systems in the Republic was aimed at the interest of the cotton sector. As a result, in 1960 the volume of irrigation fields was increased to 2474 thousand hectares, i.e. this result in relation to 1954 increased by 274 thousand hectares [5]. Soviet policy in the 1960 s aimed at the development of irrigation works in Uzbekistan is directly related to the process of expanding irrigation fields. In the seven years (1959-1965), large-scale construction was carried out in the irrigation system of the republic, in particular in the Ferghana and Zarafshan valleys, Khorezm and Karakalpakstan, ditch systems were built, the ameliorative condition of lands located in 700 thousand hectares of fields was improved, the irrigation fields were expanded on 500 thousand hectares. It should be noted that in Soviet times, due to the efforts of the leadership of the republic, as well as, due to the introduction of large investments in Uzbekistan from the budget of the Union, large-scale irrigation agriculture developed in 1960-1970. On the one hand, this made it possible to solve, to a certain extent, the problem of demography and provide jobs in the republic by attracting a large part of the population to production in agriculture. At the same time, massive land reclamation led to severe environmental consequences: the Aral Sea began to shallow rapidly large areas were salinized and became unusable $[6$, p.214]. The Soviet authorities in the republic, in order to increase the continuous yield obtained from cotton, determined the importance of the implementation of reclamation measures to cultivate the lands and improve their condition. As a result of this policy, having reclaimed lands that had not been used before, they introduced them to agricultural consumption. According to the decree of the plenum of the Central Committee of the CPSU "On the broad development of land reclamation" of May 1966, a program was developed to improve 
the land reclamation state [7, p.230]. This program was directly introduced into the agricultural sector of Uzbekistan.

As a result of the measures carried out in the spheres of irrigation and reclamation in the eleventh five-year plan (1981-1985), 238.6 thousand hectares of new irrigated land were developed, 461 thousand hectares of the land reclamation state were improved, 300 thousand hectares of irrigation lands were leveled, 4 new reservoirs, including the Andizhan water reservoir, with a capacity of 1900 million $\mathrm{m}^{3}$, was put into operation. In the Tuyamuyin hydrosystem, in the reservoirs of Hisaraka, Zamina, Akdarya, Karavultapa, Aktepa, work was completed [8]. It should be noted that the ambivalent policy pursued by the Soviet regime in irrigation has led to a number of negative phenomena. For example, due to the watercourses of the collector, the degree of mineralization of river water has increased, as a result, the land reclamation state of the republic has worsened the amount of saline lands has increased sharply. The malfunction of the land reclamation state intensified the deformation processes in the sphere of irrigation. The structure of sown fields in relation to the previous periods has changed a lot. In the republic, out of all irrigated lands, 75 percent were cotton fields. The cotton monopoly, which has intensified in the agriculture of Uzbekistan, ruined the irrigation traditions and crop rotation systems that had been formed in the republic for several years. During the Soviet period, in order to irrigate the existing cotton fields and collect water resources, special attention was paid to the construction of hydraulic facilities. But during the construction of reservoirs, not the human factor was a priority, but the interest of the cotton sector of the Soviet government. To achieve this goal, many reservoirs and canals were built. To improve their technical condition, many orders and instructions were received from the center. In particular, in the order of the Ministry of
Water Resources of the Republic "On the construction of a temporary spillway system in the Tudakul reservoir", the task of building a water discharge from the reservoir 100 million $\mathrm{m}^{3}$ was entrusted to the heads of the water industry [9]. In 1957 in Yakkabagdarya the construction of the Kamashi reservoir and in 1963 the Chimkurgan reservoir was completed. As a result, the supply of water to irrigated lands in Kashkadarya region has significantly increased. If in 1962 before the launch of the Chimkurgan reservoir, in the region there was a continuous cotton harvest of 139 thousand tons, then this figure in 1966 was 218 thousand tons or $57 \%$ [10, p.99].

As mentioned above, the main goal outlined during the construction of reservoirs in the republic was the conservation of water resources and their use in the interests of cotton growing. Therefore, the policy implemented for the construction of reservoirs by the decision-making bodies of the USSR expanded year after year. In particular, in the republic in 1981-1990, due to irrigation construction, the number of reservoirs reached 23, construction continued on 15, and 6 reservoirs were being designed [11]. During the Soviet period, recumbent and standing drainage networks, canals and pumping stations, which were used in agriculture, were continued in the irrigation system of Uzbekistan. The use of these facilities in the republic has helped the development of cotton growing. Therefore, measures were taken to improve the technical serviceability of canals and pumping stations. In particular, on July 12, 1952, according to the order of the USSR Ministry of Cotton Growing "On measures for the technical improvement of the Huge Ferghana Canal" [12], the technical condition of the Huge Ferghana Canal was improved, which led to the intensification of cotton growing in the Ferghana Valley. In 1953, on the section of the Huge Ferghana Canal from the Kuyganer dam to the Asaka siphon and in the South Ferghana Canal, a full clean-up work was 
carried out. In the channel, the water flowed full, cotton fields expanded. But as a result of the rise of groundwater, the circle was saline. Beginning from 1960-1970, in order to meet the needs of cotton growing of the Soviet regime, the construction of canals was further intensified. In particular, on February 17, 1970, the Central Committee of the Communist Party of Uzbekistan and the Council of Ministers of the Uzbek SSR adopted a resolution "On the second stage of construction of the Amu-Bukhara Canal" [13]. Water supply through the valley of small Zarafshan and Amu Darya for the construction of the first stage of the AmuKarakul and Amu-Bukhara canals, the supply of water to irrigation lands in the regions of Bukhara, Samarkand and Kashkadarya has increased markedly. The use of the second stage of the canal, the cultivation of cotton contributed to the increase to 100 thousand tons, as well as the receipt of additional products from horticulture, the full use of agricultural capabilities in production. Since the 70-80s of the XX century in the field of agriculture, the republic attached importance to extensive development. As a result, the volume of irrigated land in 1950 increased from 2276 thousand hectares by 1986 to 4020 thousand hectares. The increase in the volume of irrigated land had almost no effect on the quality and efficiency of agricultural production. On the contrary, the size of the harvest per hectare decreased year after year. In 1986, due to re-salinization, one third of the sown irrigation fields were affected. In the 70-80s, due to the deterioration of the ameliorative state, almost 5 thousand hectares of irrigated land were withdrawn from agricultural consumption [14, p.554].

In the republic, the area of cotton sown fields from 1960 to 1980 increased by 30\%, their volume having come to 1980 was 2 million hectares. As a result, the priority of the cotton monopoly was ensured in the field of agriculture. Under the policy of the center, based on the administrative-compulsory method, the process of collecting cotton raw materials called "white gold" was aggravated in any way [15, p.6]. Under the influence of the agrarian policy of the Soviet government, cotton fields were created in territories where water did not rise naturally, and pumping stations were built for their irrigation. In 1955-1959, 9 pumping stations were launched in the Ferghana Valley [16, p.75], providing water for 10 thousand hectares. In the republic, the total length of collector-drainage networks has reached 37 $\mathrm{km}$. In order to reduce the loss of water, for seven years (1959-1965) in areas of low water, $545 \mathrm{~km}$ of canals were concreted [17]. In 1965, 2090 pumps were used in the irrigation system of the UzSSR [18]. During this period, the largest use of pumps in the irrigation system falls on the Samarkand regions - 400, Bukhara - 391. But, the spillage of water in the collector-drainage basins, the degree of mineralization of the springs in the basins increased. Every year from the collectordrainage in the Amu Darya water was spilled 3 billion $\mathrm{m}^{3}$, mineralization 1-4 grams. In 19701985, the salinity of the Amu Darya water doubled. Because from the regions of Karshi, Bukhara, Surkhandarya every second 40-60 $\mathrm{m}^{3}$ were spilled into the Amu Darya per 18 grams of salt water. The water of the Syr Darya was mineralized in its composition you can see 1.29 grams of salt [19]. Subsequently, this had a negative impact on the development of fishing [20, p.311].

\section{CONCLUSION}

To sum up, other negative consequences were the transformation of the Aral Sea region into a hotbed of diseases, in particular, the highest rate of throat cancer. Also, in the northwestern part of the republic, newborn mortality has risen to a high degree. Pollution of the internal river basins by various gravity influences on people's health and caused the spread of stomach diseases, epidemics of cholera, tuberculosis, hepatitis and other diseases. 


\section{REFERENCES}

1. National Archives of the Republic of Uzbekistan (Nar Uz), R.fund.837, list.38, work 3803, p.234.

2. Begmatov I., Mukhamedov A. History of irrigation in Uzbekistan.-Tashkent: TIMI, 2008.

3. Igamberdiev R.S., Razzakov A.A. History of land reclamation in Uzbekistan (on the materials of the Mirzachul).- Tashkent: Fan, 1978.

4. XX Congress of the Communist Party of the Soviet Union. February 14-25, 1956: Stenographic report I.-Tashkent: Uzdavnashr, 1957.

5. Nar Uz, R.fund.2483, list 1, work 345, p.46.

6. Rashidova G., Komilov D. Sharof Rashidov: Man in the mirror of time and time in the destiny of man.-Tashkent: Tasvir, 2017.

7. Rizaev G. Socialist agriculture of Uzbekistan.-Tashkent: Uzbekistan, 1978.

8. Sapoev K. Let us increase the efficiency of land reclamation // Agriculture of Uzbekistan. -Tashkent, 1986. -№2.

9. Nar Uz, R.fund.2483, list 1, work.954, p.38.

10. Mamedov A. Irrigation and irrigators of Uzbekistan.-Tashkent: Uzbekistan, 1971.

11. Akramov Z.M., Rafikov A.A. Past, present and future of the Aral Sea.-Tashkent: Mekhnat, 1989.

12. State Archives of Andizhan region, fund 602, list 1, work 56, p.39.

13. Nar Uz, R.fund.2700, list 1, work 742, p.167.

14. New history of Uzbekistan. The second book. Uzbekistan during the Soviet colonial period.-Tashkent: Shark, 2000.

15. Spoor M. Agricultural Restructuring and Trends in Rural Inequalities in Central Asia: A Socio-Statistical Survey. Programme on Civil Society and Social Movements -Geneva: UNRISD, 2004.

16. History of collective and state farms of Uzbekistan (Essays). The first book.
Editor-in-Chief: M.G. Vakhobov.Tashkent: Uzbekistan, 1969.

17. Irrigation and land reclamation - the way to high and sustainable yields // Pravda Vostoka, June 22, 1966

18. Nar Uz, R.fund.2676, list 1, work 1010, p.80.

19. Yusupov E., Ziyadullaev S. Aral to live! Aral-to develop // Pravda Vostoka, July 7, 1987

20. Enger E., Smith B. Environmental Science. A study of Interrelationships. Fifth edition. -USA: The McGraw-Hill Companies, 1995. 